\title{
The Processing of Compound Noun in Children with Poor Reading Comprehension
}

\author{
Jung Ihn Hahn ${ }^{\mathrm{a}}$, Mina Hwang ${ }^{\mathrm{b}}$, Sunhee $\mathrm{Ko}^{\mathrm{c}}$ \\ ${ }^{a}$ Graduate School of Special Education, Dankook University, Yongin, Korea \\ ${ }^{b}$ Department of Special Education, Dankook University, Yongin, Korea \\ ${ }^{c}$ Graduate School of Special Education, Kongju University, Gongju, Korea
}

\section{Correspondence: Sunhee Ko, $\mathrm{PhD}$}

Graduate School of Special Education, Kongju University, 56 Gongjudaehak-ro, Gongju 32588, Korea

Tel: +82-41-850-8409

Fax: +82-41-850-8410

E-mail: sun7610@hanmail.net

Received: January 5, 2018

Revised: February 21, 2018

Accepted: February 21, 2018

\begin{abstract}
Objectives: Poor comprehenders lack vocabulary knowledge and have inefficient meaning processing abilities, which negatively affects their reading comprehension. This study investigated if poor comprehenders differ from good comprehenders when processing the meanings of compound nouns. Methods: The participants were 10 poor comprehenders and 10 good comprehenders in 3-5 grade. Accuracy and the response times were measured while children performed a priming lexical decision task. In this task, compound nouns were divided into high and low frequency conditions, and priming words were divided into conditions related to the modifier of the compound noun (modifier condition) and conditions related to the head of the compound noun (head condition). Results: Poor comprehenders showed lower accuracy and longer response times than good comprehenders. Both groups showed lower accuracy and longer response time in the low frequency condition than the high frequency condition. Also, both groups showed shorter response times in the head condition than the modifier condition. However, in case of the poor comprehenders, accuracy was significantly lower under the low frequency modifier condition, and response times were significantly longer under the low frequency condition. Conclusion: Overall, poor comprehenders had difficulty in processing the meaning of compound nouns. This could be a result of weak organization of semantic networks in their mental lexicon. In addition, it could be affected by a lack of understanding of syntactic structures and the semantic relations of compound nouns.
\end{abstract}

Keywords: Poor comprehender, Compound noun, Lexical decision task
읽기는 단순히 글자를 읽는 것에 그치는 것이 아니라 보다 높은 수준의 지적 사고 과정을 통해 읽은 내용을 총체적으로 이해하는 것을 의미한다(Kamhi \& Catts, 2005). 이 같은 읽기 능력을 향상시 키기 위해 학령기 전후의 아동들은 음독 능력을 확립하는 데 주력 을 하지만 학년이 올라갈수록 음독 능력은 안정기에 접어들고 읽기 이해의 중요성이 부각되게 된다. 그러나 일부 아동들은 연령에 적 합한 수준의 음독 및 단어 재인 능력을 가지고 있음에도 읽은 내용 을 이해하는 데 어려움을 보이는데 이들을 읽기이해부진 아동이라 한다(Cain \& Oakhill, 2008; Nation, 2005). 학령기 아동들이 읽기 이해에 어려움을 보인다면 이는 새로운 지식을 탐색하고 교과 내용 을 학습하는 데 부정적인 영향을 미칠 수 있기에 여러 연구들에서
읽기이해부진 아동들이 읽기 이해에 실패하는 원인들을 규명하고 자 이들의 언어 및 인지적인 특성을 연구해 왔다. 그 결과, 읽기이해 부진 아동들은 읽기 이해를 위해 필수적인 요소인 어휘, 추론, 작업 기억 등에 결함이 있는 것으로 확인되었다(Borella, Carretti, \& Pelegrina, 2010; Choi \& Hwang, 2010; Chung, 2009; Kim \& Hwang, 2017; Ko, Choi, \& Hwang, 2010; Nation, Clarke, \& Snowling, 2002; Nation, Cocksey, Taylor, \& Bishop, 2010; Yu \& Kim, 2017).

이 중에서도 어휘 능력은 읽기 이해를 위해 중요한 역할을 하게 되는데(Cain \& Oakhill, 2006; Cunningham \& Stanovich, 1997; Joshi \& Aaron, 2000; Nagy \& Scott, 2000; Nation \& Snowling, 1998), 아동들은 다양한 읽기를 경험하면서 새로운 어휘들을 습득하게 
되고, 이렇게 습득된 어휘 및 어휘 지식들은 다시 보다 고차원적인 읽기 이해를 가능하게 할뿐만 아니라 읽기 이해의 효율성을 높이 는 원동력이 된다. 또한, 어휘는 학령기 아동들의 읽기 이해 능력을 설명할 수 있는 중요한 변인이기에(Jeong, 2013; Joshi \& Aaron, 2000;

Kim, Yoo, Hwang, Kim, \& Koh, 2010; Nation \& Snowling, 1998), 본 연구에서는 읽기이해부진 아동들이 어휘 중에서도 복합명사 (compound noun)의 의미를 처리하는 데 있어 일반 아동들과 어떠 한차이가 있는지를 알아보고자 하였다.

복합명사는 두 개 이상의 명사가 합쳐져 만들어진 단어를 말하 며, 이는 어휘의 생산성(lexical productivity)을 높이기 위해 대부 분의 언어에서 보편적으로 나타나는 형태이다(Libben, 2014). 복합 명사의 분류는 연구자들마다 다소 차이가 있기는 하지만 크게 대 등 복합명사(예: 논밭, 밤낮), 종속 복합명사(예: 손수건, 산나물), 융 합 복합명사(예: 오리발, 콩밥)로 분류할 수 있다(Wang \& Min, 1997). 이중에서도 종속 복합명사는 수식어+핵심어의 구조를 가지면서 의미 투명도가 높아 원래의 의미를 잃지 않고 전체 단어의 뜻도 유 지되는 특성이 있다. 종속 복합명사는 다른 형태의 복합명사들에 비해 초등학교 교과 과정에서도 높은 빈도로 출현하기에 본 연구에 서는 종속복합명사(이하 복합명사)의 의미 처리 특성을 살펴보았다.

아동들이 복합명사를 습득하는 과정을 살펴보면, 2 세 경에 단순 한 복합명사의 기능을 이해하기 시작하고, 3 세 경이 되면 새로운 복 합명사를 접했을 때도 그 의미를 이해할 수 있으며, 연령이 점차 증 가하면서 언어 표현을 풍성하게 하기 위한 목적으로 복합명사의 사 용이 나타난다(Berman, 2009; Clark, Gelman, \& Lane, 1985). 또 한, 아동들이 4-5세가 되면 복합명사의 수식어는 세부 범주를, 핵 심어는 일반적인 범주를 의미한다는 것을 경험적으로 이해할 수 있 게 된다(Nicoladis \& Krott, 2007). 이후 아동들이 학령기에 접어들 면 학교 교과 과정 중에 복합명사의 구조적인 특성을 배우게 되는 데 이때 복합명사의 각 형태소들이 갖고 있는 의미와 전체의 의미 를 연결하는 것을 직접적으로 학습하게 된다.

일반적으로 대부분의 단어가 하나의 형태소로 구성되어 있는데 반해 복합명사는 여러 개의 형태소가 합쳐져 하나의 단어를 이루 기 때문에 글을 읽는 중에 복합명사를 접했을 때 단어 내의 형태적 인 구조 및 의미 관계를 파악하여 의미를 처리해야 한다(Nicoladis, 2002). 즉, 복합명사에 포함된 개별 형태소들의 의미들에 빠르게 접 속하여 그 의미들을 통합해야 하는 것이다. 따라서 본 연구에서는 점화 어휘 판단 과제(priming lexical decision task)를 사용하여 읽 기이해부진 아동들이 복합명사를 접했을 때 단어 내에 포함하고 있는 개별 형태소의 의미를 효율적으로 처리하는지를 알아보았다. 이때 제시되는 복합명사는 고빈도 조건과 저빈도 조건으로 나뉘
고, 복합명사 앞에 제시되는 점화 단어는 복합명사의 수식어와 관 련이 있는 조건(이하 수식어 점화 조건)과 복합명사의 핵심어와 관 련이 있는 조건(이하 핵심어 점화 조건)으로 나뉜다. 일반적으로 고 빈도의 복합명사가 저빈도의 복합명사에 비해 이해하는 것이 수월 하고(McGregor, Rost, Guo, \& Sheng, 2010), 고빈도 복합명사는 단 어 내의 개별 형태소의 의미와 전체 의미가 동시에 활성화되는 데 비해 저빈도 복합명사는 개별 형태소의 의미 처리에 더 의존하는 경향을 보인다(Lee, 2005). 또한 아동들은 발달적으로 복합명사의 수식어보다 핵심어를 먼저 습득할뿐만 아니라 핵심어가 일반적인 범주를 결정하기 때문에 복합명사의 의미를 처리하는 데 있어 보다 중요한 역할을 하게 된다(Chen, Hao, Geva, Zhu, \& Shu, 2009). 이 같은 복합명사의 처리 특성을 고려한다면 아동들 역시 저빈도 조 건에서보다 고빈도 조건에서, 수식어 점화 조건에서보다 핵심어 점 화 조건에서 복합명사가 단어임을 보다 정확하고 빠르게 판단할 것 으로 예상할 수 있다. 그러나 읽기이해부진 아동들은 어휘의 의미 처리에 있어 일반 아동들에 비해 저조한 수행을 보이는 것으로 확 인되는 바(Choi \& Hwang, 2010; Jeong, 2009; Ko et al., 2010) 복합 명사의 의미 처리에서도 어려움을 보일 수 있다.

종합하여 볼 때, 읽기이해부진 아동들의 경우 어휘 지식의 부족 하거나 어휘 의미 처리의 비효율성이 읽기이해에 부정적인 영향을 미칠 수 있기에, 어휘의 한 유형인 복합명사를 중심으로 읽기이해 부진 아동들의 의미 처리 특성을 알아보는 것도 의미가 있을 것이 다. 이에 본 연구에서는 어휘 판단 과제를 사용하여 읽기이해부진 아동들이 복합명사의 빈도와 점화 위치에 따라 복합명사의 의미를 처리함에 있어 일반 아동들과 차이가 있는지를 조사하였다.

\section{연구방법}

\section{연구대상}

본 연구는 서울, 경기 지역에 거주하는 8-10세인 초등학교 3-5학 년의 읽기이해부진 아동 10 명과 일반 아동 10 명을 대상으로 하였다.

읽기이해부진 아동들의 경우 (1) 부모나 지역아동센터 교사에 의해 읽기이해에 어려움이 있는 것으로 보고된 아동들 중에서, (2) 국립특수교육원 기초학력검사(Korean Institute for Special Education-Basic Academic Achievement Tests, KISE-BAAT; Park, Kim, Song, Jung, \& Jung, 2008)의 읽기 소검사 중 짧은 글 이해에서 $25 \%$ ile 이하에 속하고, 음독에서는 $25 \%$ ile 이상에 속하며, (3) 한국판 웩슬 러 아동용 지능검사(Korean Wechsler Intelligence Scale for Children-III, K-WISC-III; Kwak, Park, \& Kim, 2001) 결과 동작성 지능 이 85 이상이며, (4) 청각 및 신경학적 문제가 없으며 정서.행동상 
Table 1. Participants' characteristics

\begin{tabular}{lccc}
\hline & $\begin{array}{c}\text { Poor compre- } \\
\text { henders (N=10) }\end{array}$ & $\begin{array}{c}\text { Good compre- } \\
\text { henders (N=10) }\end{array}$ & $t$ \\
\hline Age (mo) & $122.4(10.24)$ & $127.3(7.97)$ & -1.194 \\
Performance IO & $98.30(10.86)$ & $107.80(13.41)$ & -1.741 \\
Decoding (score) & $22.80(1.23)$ & $23.60(1.51)$ & -1.302 \\
Comprehension (score) & $5.30(2.45)$ & $20.00(4.71)$ & $-8.749^{* * *}$ \\
\hline
\end{tabular}

Values are presented as mean (SD).

${ }^{* * *} p<.001$.

의 문제가 없는 아동으로 선정하였다. 선정된 읽기이해부진 아동 들은 남자 4 명, 여자 6명이었다.

일반 아동의 경우 (1) 부모와 교사에 의해 읽기 이해의 어려움이 없는 것으로 보고된 아동들 중에서, (2) 기초학력검사의 읽기 소검 사 중 짧은 글 이해와 음독 모두에서 $25 \%$ ile 이상에 속하고, (3) KWISC-III의 동작성 지능이 85 이상이며, (4) 청각 및 신경학적 문제 가 없으며 정서.행동상의 문제가 없는 아동들로 선정하였다. 선정 된 일반 아동들은 남자 4 명, 여자 6 명이었다.

읽기이해부진 아동과 일반 아동 간 연령, 동작성 지능, 읽기 이해 및 음독 능력에 차이가 있는지를 확인하기 위해 $t$-검정을 실시하였 다. 그 결과, 연령, 동작성 지능, 음독에서는 집단 간 차이가 유의미 하지 않았지만, 읽기이해에서는 유의한 차이가 나타났다 $(t=8.749$, $p<.001)$. 본 연구에 참여한 아동들에 대한 정보는 Table 1 과 같다.

\section{연구도구}

본 연구에서는 읽기이해부진 아동과 일반 아동의 복합명사 의미 처리 특성을 살펴보고자 어휘 판단 과제를 사용하였다. 아동들에 게 점화 단어와 목표 단어가 제시되는데 아동들은 점화 단어를 읽 은 직후에 제시되는 목표 단어가 단어인지 아닌지를 판단해야 한 다. 이때 목표 단어는 고빈도 또는 저빈도의 수식어-핵심어 구조의 복합명사이며, 점화 단어는 복합명사의 수식어 부분의 의미와 관 련이 있는 단어가 제시되는 조건 또는 핵심어의 의미와 관련이 있 는 단어가 제시되는 조건으로 구성하였다. 이 같은 과제를 제작하 기 위하여 다음과 같은 과정을 거쳤다.

고빈도 복합명사 선정을 위해 초등학교 1학년부터 3학년 1학기 까지의 읽기 교과서에 나오는 복합명사와 Kim (2003)의 등급별 어 휘에서 1,2 등급에 해당하는 복합명사 110 개를 우선 선별하였다. 그 후 초등학교 3 학년 아동 10 명을 대상으로 110 개의 복합명사에 대한 친숙도를 5 점 척도(아주 많이 들어봤다 $=5$, 조금 많이 들어봤 다 $=4$, 보통으로 들어봤다 $=3$, 가끔 들어봤다 $=2$, 전혀 들어본 적 이 없다=1)로 평가하도록 하여 평균이 3점 이상인 단어 96 개를 선 정하였다. 저빈도의 복합명사 선정을 위해서는 $\operatorname{Kim}$ (2003)의 등급
별 어휘에서 4 등급에 해당하는 단어이면서 현대 국어사용 빈도 조 사(National Institute of the Korean Language, 2005)에서 빈도 30 미만의 복합명사 90 개를 선별하였다. 그 후 초등학교 5학년 아동을 대상으로 90 개의 복합명사에 대한 친숙도를 5 점 척도로 평가하도 록 하여 평균이 3 미만인 단어 50 개를 선정하였다.

복합명사의 수식어 또는 핵심어와 관련된 점화 단어를 선정하기 위해 언어치료사들과 아동들을 대상으로 1 차, 2 차에 걸쳐 의미 관 련성 설문 조사를 실시하였다. 이를 위해 복합명사(예: 짚불, 짚방 석)를 단단어(예: 짚, 불, 방석)로 분리한 후 단단어 목록을 만들어 10 명의 언어치료사에게 제시한 후 각각의 단어를 보고 연상되는 3 음절 이하의 단어를 3 개씩 기록하도록 하였다. 각각의 단단어에 대 해 일치율이 높은 순서로 4 개의 연상 단어를 선별하였다. 이 과정에 서 최소 4 명의 언어치료사들에게서 공통적으로 연상되는 단어가 없는 단단어가 포함된 복합명사는 과제 제작 후보단어에서 탈락시 켰다. 2 차 의미 관련성 설문조사는 초등학교 3 학년 아동 10 명에게 실시하였다. 아동들에게 각각의 단단어에 대해 1 차 설문조사에서 연관성이 높은 것으로 조사된 4 개의 단어를 보기로 제시하고 가장 관련이 있다고 생각하는 단어를 선택하도록 하여 아동들끼리 일치 도가 높은 단어들을 중심으로 복합명사의 점화 단어로 선정하였다.

최종 선정된 복합명사는 고빈도 단어 30 개, 저빈도 단어 30 개로 각 조건당 2 음절 단어 4 개, 3 음절 단어 20 개, 4 음절 단어 6 개로 구 성되었다. 다시 고빈도 복합명사 30 개와 저빈도 복합명사 30 개는 반 으로 나누어 각각 15 개는 수식어 점화 조건으로 나머지 15 개는 핵 심어 점화 조건으로 하여 최종 60 문항을 제작하였다. 그 문항의 예 는 Appendix 1과같다.

본 문항에 포함된 복합명사에 대해 어휘 판단을 하였을 때 모두 '예’ 반응을 해야 하기 때문에 ‘아니오' 반응을 이끌어 내기 위하여 점화단어와비단어 쌍 60개(foil)를 제작하였다. 비단어는 Kim (2003) 의 1,2 등급 단어 60 개를 선정하여 이들 단어의 각 음절의 모음을 변형시켰고, 각 단어의 일부 초성을 변형시킴으로써 제작하였다 (예: '이발소' $\rightarrow$ '애벌수' $\rightarrow$ '애뻘수').

\section{연구절차}

본 실험을 위해 과제는 $\mathrm{DmDX}$ v5.1.1.4 프로그램을 사용하여 제 작하였으며, 실험을 위해 노트북(LG Gram i7)을 사용하였다. 과제 는 30 개의 연습 문항과 120 개의 본 문항으로 구성되었다.

본 실험에 들어가기에 앞서 실험자는 아동들에게 과제가 어떻게 진행이 되며 어떻게 반응해야 하는지를 시각적인 자료를 활용하여 설명해 주었고, 이후 아동들의 질문을 받아 그에 대해 자세히 답해 주었다. 먼저 아동들에게 "모니터를 보고 있으면 더하기(+)가 나왔 
다가 사라지고 글자가 나타나는데 첫 번째 단어가 나타났다가 사라 진 후 두 번째 단어가 제시되면 그 단어가 단어인지 아닌지 판단해 야 해요. 만약 단어이면 ‘예' 버튼을, 이상한 단어이면 ‘아니오' 버튼 을 누르세요. 모니터를 잘 보고 가능한 정확하고 빠르게 판단해서 버튼을 누르는 것이 중요해요”라고 설명해 주었다.

어휘 판단 과제는 먼저 모니터의 중앙에 응시점(+)이 $250 \mathrm{~ms}$ 동 안 제시된다. 응시점이 사라짐과 동시에 점화 단어가 $250 \mathrm{~ms}$ 제시 되었다 사라지면 목표 단어가 제시된다. 목표 단어는 $5,000 \mathrm{~ms}$ 제시 되지만 아동이 그 시간 안에 반응을 하면 자동으로 그 문항이 종료 된다. 아동들은 30 개의 연습 문항을 실시한 후 본 문항을 실시하였 다. 본 문항을 실시할 때 과제에 대한 피로도를 조절하기 위해 60 문 항을 마친 다음 휴식을 취하도록 하였고 다시 60 문항을 진행하였다.

\section{자료분석}

'아니오' 반응을 유도하기 위해 포함된 비단어 문항 60 개는 본 자 료 분석에서 제외되었으며, '예'라고 반응한 복합명사 문항에 대해 서만 분석을 하였다. 이때 정확히 반응하였다 하더라도 반응시간 이 $250 \mathrm{~ms}$ 이하이거나 개인의 평균 반응시간의 $+2 \mathrm{SD}$ 에 해당하는 반응은 과제 집중에 문제가 있었을 것으로 간주하여 분석 대상에 서 제외하였다.

읽기이해부진 아동과 일반 아동이 복합명사의 빈도(고빈도/저빈 도) 및 점화 위치(수식어 점화/핵심어 점화)에 따라 반응정확도와 반응시간에 차이가 있는지를 알아보기 위하여 집단(2) $\times$ 빈도 $(2) \times$ 위치(2)의 삼요인 반복측정 분산분석을 실시하였다. 자료의 통계 처 리를 위해 SPSS version 18.0 for Windows 프로그램을 사용하였다.

\section{연구결과}

읽기이해부진 아동과 일반 아동의 어휘 판단 과제에 대한 반응 정확도와 반응시간에 대한 기술통계 결과는 Table 2 와 같다.

읽기이해부진 아동과 일반 아동 간 복합명사 빈도와 점화 위치 에 따른 어휘 판단 반응정확도에 있어 차이가 있는지를 알아보기
위하여 삼요인 분산분석을 실시하였다(Table 3). 그 결과, 집단 주효 과 $\left(F_{(1,18)}=5.292, p<.05\right)$, 빈도 주효과 $\left(F_{(1,18)}=56.488, p<.001\right)$, 집 단, 빈도와 위치 상호작용 효과 $\left(F_{(1,18)}=7.054, p<.05\right)$ 가 유의미하였 으나 위치 주효과, 집단과 빈도 상호작용 효과, 집단과 위치 상호작 용 효과, 빈도와 위치 상호작용 효과, 집단, 빈도와 위치의 상호작용 효과가 유의미하지 않았다.

빈도, 위치와 집단 상호작용 효과를 확인하기 위하여 두 집단 간 고빈도 수식어 점화, 고빈도 핵심어 점화, 저빈도 수식어 점화, 저빈 도 핵심어 점화 조건 각각에 대해 독립표본 $t$-검정을 실시하였다. 그 결과 저빈도 수식어 점화 조건에서만 두 집단 간의 수행 차이가 유 의미하였다 $(t=2.929, p<.001)$.

읽기이해부진 아동과 일반 아동 간 복합명사 빈도와 점화 위치 에 따른 어휘 판단 반응시간에 있어 차이가 있는지를 알아보기 위 하여 삼요인 분산분석을 실시하였다(Table 4). 그 결과, 집단 주효과 $\left(F_{(1,18)}=15.049, p<.001\right)$, 빈도 주효과 $\left(F_{(1,18)}=126.503, p<.001\right)$, 위치 주효과 $\left(F_{(1,18)}=5.907, p<.05\right)$, 집단과 빈도 상호작용 효과 $\left(F_{(1,18)}=\right.$

Table 3. Result of three-way ANOVA on reaction accuracy of lexical decision task

\begin{tabular}{|c|c|c|c|c|}
\hline Source & $\begin{array}{l}\text { Type III sum } \\
\text { of squares }\end{array}$ & $d f$ & $\begin{array}{l}\text { Mean } \\
\text { square }\end{array}$ & $F$ \\
\hline \multicolumn{5}{|l|}{ Between group } \\
\hline Group & 781.375 & 1 & 781.375 & $5.292^{*}$ \\
\hline Error & $2,657.766$ & 18 & 147.654 & \\
\hline \multicolumn{5}{|l|}{ Within group } \\
\hline Frequency & $8,564.419$ & 1 & $8,564.419$ & $56.488^{* * *}$ \\
\hline Frequency $\times$ Group & 241.165 & 1 & 241.165 & 1.591 \\
\hline Error & 2,729.089 & 18 & 151.616 & \\
\hline Location & .386 & 1 & .386 & .019 \\
\hline Location × Group & 65.161 & 1 & 65.161 & 3.269 \\
\hline Error & 358.793 & 18 & 19.933 & \\
\hline Frequency $\times$ Location & 31.200 & 1 & 31.200 & .913 \\
\hline Frequency $\times$ Location $\times$ Group & 240.957 & 1 & 240.957 & $7.054^{*}$ \\
\hline Error & 614.887 & 18 & 34.160 & \\
\hline
\end{tabular}

${ }^{*} p<.05,{ }^{* * *} p<.001$.

Table 2. Reaction time and accuracy of lexical decision task

\begin{tabular}{|c|c|c|c|c|c|c|c|c|}
\hline & \multicolumn{4}{|c|}{ High frequency } & \multicolumn{4}{|c|}{ Law frequency } \\
\hline & \multicolumn{2}{|c|}{ Frond } & \multicolumn{2}{|c|}{ Back } & \multicolumn{2}{|c|}{ Frond } & \multicolumn{2}{|c|}{ Back } \\
\hline & $\mathrm{RA}(\%)$ & $\mathrm{RT}(\mathrm{ms})$ & $\mathrm{RA}(\%)$ & $\mathrm{RT}(\mathrm{ms})$ & $\mathrm{RA}(\%)$ & $\mathrm{RT}(\mathrm{ms})$ & $\mathrm{RA}(\%)$ & $\mathrm{RT}(\mathrm{ms})$ \\
\hline Poor comprehender & $96.11(3.75)$ & 978.28 (236.69) & $93.33(5.10)$ & $923.85(194.43)$ & $67.22(13.21)$ & 1,229.88 (186.17) & $73.88(14.59)$ & 1,224.87 (326.03) \\
\hline Good comprehender & $97.22(3.93)$ & 725.74 (66.35) & $97.77(5.37)$ & 691.51 (48.41) & $82.22(9.36)$ & 899.39 (144.34) & $78.33(12.12)$ & 840.52 (136.04) \\
\hline
\end{tabular}

Values are presented as mean (SD).

$\mathrm{RA}=$ reaction accuracy; $\mathrm{RT}=$ reaction time. 
Table 4. Result of three-way ANOVA on reaction time of lexical decision task

\begin{tabular}{|c|c|c|c|c|}
\hline Source & $\begin{array}{l}\text { Type III sum } \\
\text { of squares }\end{array}$ & $d f$ & $\begin{array}{l}\text { Mean } \\
\text { square }\end{array}$ & $F$ \\
\hline \multicolumn{5}{|l|}{ Between group } \\
\hline Group & $1,799,091.823$ & 1 & 1,799,091.823 & $15.049 * * *$ \\
\hline Error & $2,151,811.805$ & 18 & $119,545.100$ & \\
\hline \multicolumn{5}{|l|}{ Within group } \\
\hline Frequency & $957,636.565$ & 1 & $957,636.565$ & $126.503^{* * *}$ \\
\hline Frequency × Group & $66,103.515$ & 1 & $66,103.515$ & $8.732^{* *}$ \\
\hline Error & $136,261.596$ & 18 & $7,570.089$ & \\
\hline Location & $29,079.898$ & 1 & $29,079.898$ & $5.907^{*}$ \\
\hline Location× Group & $1,416.427$ & 1 & $1,416.427$ & .288 \\
\hline Error & $88,619.436$ & 18 & 4,923.302 & \\
\hline Frequency × Location & 767.887 & 1 & 767.887 & .091 \\
\hline Frequency $\times$ Location $\times$ Group & $6,855.222$ & 1 & $6,855.222$ & .816 \\
\hline Error & $151,164.373$ & 18 & $8,398.021$ & \\
\hline
\end{tabular}

${ }^{*} p<.05,{ }^{* *} p<.01,{ }^{* * *} p<.001$.

$8.732, p<.01)$ 가 유의미하였고, 집단과 위치 상호작용 효과, 빈도와 위치 상호작용 효과, 집단, 빈도와 위치의 상호작용 효과는 유의미 하지 않았다.

집단과 빈도 상호작용 효과를 확인하기 위하여 읽기이해부진 아 동과 일반 아동 간 저빈도와 고빈도 조건에서의 반응시간 차에 대 한 독립표본 $t$-검정을 실시하였고 그 결과 집단 간의 차이가 유의미 한 것으로 나타났다 $(t=3.074, p<.01)$.

\section{논의 및 결론}

본 연구에서는 읽기이해부진 아동들이 복합명사의 의미를 처리 하는 데 있어 일반 아동들과 차이가 있는지를 알아보고자 복합명 사의 빈도와 점화 위치를 달리 하여 어휘 판단 과제를 실시하였고, 이에 대한 어휘 판단 정확도와 반응시간을 측정하여 분석하였다. 정확도 측면에서 보면, 읽기이해부진 아동들이 일반 아동들에 비 해 낮은 정확도를 보였고, 읽기이해부진 아동들과 일반 아동들 모 두 고빈도 조건에 비해 저빈도 조건에서 정확도가 낮았으며, 특히 읽기이해부진 아동들은 저빈도 수식어 점화 조건에서의 정확도가 현저히 낮았다. 어휘 판단 반응시간 측면에서 보면, 읽기이해부진 아동들이 일반 아동들에 비해 전반적으로 반응시간이 길었고, 읽 기이해부진 아동들과 일반 아동들 모두 고빈도 조건에 비해 저빈 도 조건에서 반응시간이 길었으며, 읽기이해부진 아동들의 경우 저 빈도 조건에서 현저히 반응시간이 길어짐을 확인할 수 있었다. 또 한 읽기이해부진 아동들과 일반 아동들 모두 수식어 점화 조건에 서보다 핵심어 점화 조건에서 반응시간이 짧았다. 이 같은 결과에
대한 논의는 다음과 같다.

첫째, 읽기이해부진 아동들은 일반 아동들에 비해 복합명사가 어휘임을 판단하는 데 있어 전반적으로 정확도가 낮았으며 반응속 도도 느렸다. 일반적으로 단어의 의미 처리는 무의식 수준에서 일 어나며, 그 과정은 단어 재인과 어휘 접속으로 나누어진다(Zoh et al., 2003). 단어 재인은 글자를 음독함으로써 형태적, 음운적, 통사 적인 정보들을 처리하여 단어를 확인하는 것이고, 어휘 접속은 심 성어휘집(lexicon) 내의 의미연결망(semantic network)을 통해 앞 서 확인된 단어의 의미를 표상하는 과정이다(Tabossi \& Zardon, 1993). 읽기이해부진 아동들은 음독이나 단어 재인에서는 일반 아 동들과 차이가 없는 것으로 보고되고 있어(Catts, Hogan, \& Fey, 2003; Dymock, 1993) 이들이 복합명사의 어휘 판단에 어려움을 보 인 것은 어휘 접속 과정에서의 문제로 해석할 수 있다. 본 연구에서 는 복합명사의 어휘 판단에 앞서 점화 단어로 복합명사의 부분 의 미와 관련된 단어를 제시하였다. 먼저 점화 단어의 의미에 접속하 고 이후 점화 단어와 의미적으로 관련이 있는 목표 단어가 제시되 면 점화 효과(priming effect)로 인해 목표 단어의 의미 처리가 수월 해진다. 이 과정에서 개인의 심성어휘집에 의미연결망이 복잡하게 조직되어 있고 의미들끼리 강하게 연결되어 있을 경우 점화 효과가 크게 나타나 목표 단어의 어휘 판단이 보다 정확하고 빨라지게 된 다(Collins \& Loftus, 1975). 이 같은 의미연결망 모델(semantic network model)에 근거하여 본다면, 읽기이해부진 아동들의 의미연 결망은 일반 아동들에 비해 덜 조직되어 있거나 강도가 약하게 조 직되어 있어 복합명사의 어휘 판단에서 저조한 수행을 보인 것으로 보이며, 이는 Choi와Hwang (2010)의 연구결과와도 일치한다.

둘째, 읽기이해부진 아동들과 일반 아동들 모두 고빈도에 비해 저빈도의 복합명사의 어휘 판단에서 정확도가 낮았고 반응속도가 느렸다. 선행연구들에서도 빈도 효과가 확인된 것으로 보아 고빈도 의 단어가 저빈도의 단어에 비해 의미 처리가 수월하며 보다 효율 적으로 처리됨을 알 수 있다(Gweon, Kim, \& Lee, 2006; Monsell, Doyle, \& Haggard, 1989). 특히 저빈도의 복합명사의 경우 복합명 사에 포함된 개별 형태소의 의미 접속을 한 후에 전체 의미를 처리 하게 되는 데 반해 고빈도의 복합명사의 경우 복합명사 내의 개별 형태소의 의미와 전체의 의미가 동시에 활성화되기 때문에(Lee, 2005) 아동들이 고빈도 복합명사에서 더 빠르고 정확하게 어휘성 을 판단했을 것이다.

셋째, 일반적으로 아동들이 저빈도 복합명사의 어휘 판단을 할 때 반응속도가 느렸지만 읽기이해부진 아동들의 경우 빈도에 더 큰 영향을 받아 저빈도 복합명사의 어휘 판단에서 현저히 느린 반 응속도를 보였다. 이로 보아 읽기이해부진 아동들이 이미 알고 있 
는 어휘들이 포함된 글을 읽는다 할지라도 자주 접하거나 사용하 지 않는 단어들이 다수 포함되어 있을 경우 의미 표상의 어려움이 가중될 수 있으며, 이는 전체적인 읽기 이해를 저해하는 주요 요인 이 될 수 있을 것이다.

넷째, 복합명사의 수식어와 관련된 단어가 점화 단어로 제시될 때와 핵심어와 관련된 단어가 점화 단어로 제시될 때 정확도에서는 전체적으로 크게 차이가 없었으나 반응시간에 있어서는 수식어 점 화 조건에 비해 핵심어 점화 조건에서 반응속도가 더 빨랐다. 실제 로 수식어 점화 조건과 핵심어 점화 조건 모두 점화 단어가 복합명 사의 부분 의미와 관련이 있기 때문에 복합명사의 어휘 판단을 하 는 데 긍정적인 영향으로 미쳤을 것이고 그로 인해 정확도에서는 큰 차이를 보이지 않았을 수 있다. 그러나 복합명사의 의미 처리에 있어 핵심어가 일반적인 의미 범주를 결정하고 그 전체 의미를 처리 하는 데 중심적인 역할을 하기 때문에(Chen et al., 2009) 핵심어와 관련된 단어가 점화 단어로 제시되었을 때 반응시간을 줄이는 데 도움이 되었을 것이다.

다섯째, 전반적으로는 점화 위치가 복합명사 어휘 판단 정확도에 영향을 미치지 않는 것으로 나타났으나 읽기이해부진 아동들의 경 우, 저빈도 수식어 점화 조건에서 복합명사의 어휘 판단 정확도가 현저히 낮았다. 앞서 언급했듯이 저빈도의 복합명사의 처리를 위해 서는 개별 형태소의 의미에 접속하여 그 통사적인 구조 및 의미 관 계를 파악하여야 하는데 이때 수식어보다 핵심어의 의미가 전체 의미 처리에 큰 비중을 차지하게 된다. 그러나 점화 단어로 수식어 와 관련된 단어가 제시됨으로 인해 수식어의 의미가 핵심어의 의미 보다 강하게 활성화되어 전체 의미 처리에 다소 혼동을 주었을 수 있을 것이다. 따라서 읽기이해부진 아동들이 저빈도 수식어 점화 조건에서 현저하게 낮은 수행을 보인 것은 빈도 효과와 점화 위치 효과가 상호작용하면서 생긴 결과이며 읽기이해부진 아동들이 단 어의 의미 처리의 미숙함이 확인되는 일례라 할 수 있겠다.

본 연구의 결과를 종합하여 볼 때, 읽기이해부진 아동들은 일반 아동들에 비해 전반적으로 복합명사의 의미 처리에 어려움을 보였 다. 복합명사는 일반적인 단어의 의미를 처리하는 과정과는 차이 가 있어, 복합명사가 어떤 형태소들이 결합되어 만들어졌는지, 그 들이 어떤 의미 관계를 이루는지, 개별 형태소들의 의미와 전체 단 어의 의미가 어떤 차이가 있는지 등을 인지하는 것이 복합명사의 이해에 영향을 미치게 된다. 또한 아동들이 이 같은 어휘 지식을 가 지고 있다면 복합명사의 의미 처리뿐 아니라 새로운 어휘 학습을 촉진하는 역할을 할 수 있기에 읽기이해부진 아동들에게도 복합명 사의 이해를 높일 수 있도록 직접적으로 중재할 필요가 있으리라 생각된다.
본 연구는 읽기이해부진 아동들의 의미 처리 특성을 밝히고자 기존에 연구되지 않았던 복합명사의 의미 처리 과정을 살펴보았다 는 점에서 의의가 있으며, 이후에 다른 유형의 복합어들을 과제로 사용하여 연구한다면 읽기에 어려움을 보이는 아동들의 의미 처리 특성을 이해하는 데 도움이 될 것이다.

\section{REFERENCES}

Berman, R. A. (2009). Children's acquisition of compound constructions. In R. Lieber \& P. Stekauer (Eds.), The Oxford handbook of compounding (pp. 298-322). Oxford: Oxford University Press.

Borella, E., Carretti, B., \& Pelegrina, S. (2010). The specific role of inhibition in reading comprehension in good and poor comprehenders. Journal of Learning Disabilities, 43, 541-552.

Cain, K., \& Oakhill, J. (2006). Profiles of children with specific reading comprehension difficulties. British Journal of Educational Psychology, 76, 683696.

Cain, K., \& Oakhill, J. (2008). Reading comprehension difficulties: correlates, causes, and consequences. In K. Cain \& J. Oakhill (Eds.), Children's comprehension problems in oral and written language: a cognitive perspective (pp. 41-75). New York, NY: Guilford Press.

Catts, H. W., Hogan, T. P., \& Fey, M. E. (2003). Subgrouping poor readers on the basis of individual differences in reading-related abilities. Journal of Learning Disabilities, 36, 151-164.

Chen, X., Hao, M., Geva, E., Zhu, J., \& Shu, H. (2009). The role of compound awareness in Chinese children's vocabulary acquisition and character reading. Reading and Writing, 22, 615-631.

Choi, K. S., \& Hwang, M. (2010). Semantic processing in children with poor reading comprehension: semantic priming effect during word reading. Korean Journal of Communication \& Disorders, 15, 168-176.

Chung, B. J. (2009). The relationships among short-term/working memory, phonological awareness, listening comprehension, and inferential skills of school-aged poor readers. Journal of Rehabilitation Research, 13, 313-327.

Clark, E. V., Gelman, S. A., \& Lane, N. M. (1985). Compound nouns and category structure in young children. Child Development, 56, 84-94.

Collins, A. M., \& Loftus, E. F. (1975). A spreading-activation theory of semantic processing. Psychological Review, 82, 407-428.

Cunningham, A. E., \& Stanovich, K. E. (1997). Early reading acquisition and its relation to reading experience and ability 10 years later. Developmental Psychology, 33, 934-945. 
Dymock, S. (1993). Reading but not understanding. Journal of Reading, 37, 86-91.

Gweon, H. W., Kim, S. K., \& Lee, H. W. (2006). The relationship between word frequency and semantic priming effects in Hangul word recognition. Korean Journal of Experimental Psychology, 18, 203-220.

Jeong, M. (2009). Verbal analogical reasoning skills in poor comprehenders. Korean Journal of Communication \& Disorders, 14, 275-287.

Jeong, M. (2013). The predictors of poor comprehenders' reading comprehension in 3 to 6 grades. The Korea Journal of Learning Disabilities, 10, 79103.

Joshi, R. M., \& Aaron, P. G. (2000). The component model of reading: simple view of reading made a little more complex. Reading Psychology, 21, 85-97.

Kamhi, A. G., \& Catts, H. W. (2005). Classification of reading disabilities. In H. W. Catts \& A. G. Kamhi (Eds.), Language and reading disabilities (2nd ed., pp. 72-93). Boston, MA: Pearson.

Kim, A. H., Yoo, H. S., Hwang, M., Kim, U. J., \& Koh, S. R. (2010). Prediction of reading comprehension in elementary school students. Korean Journal of Communication \& Disorders, 15, 357-380.

Kim, K. (2003). Vocabularies for different levels of Korean education. Seoul: Pagijung.

Kim, M. S., \& Hwang, M. (2017). Anaphor resolution in children with reading comprehension. Communication Sciences \& Disorders, 22, 512-519.

Ko, S., Choi, K. S., \& Hwang, M. (2010). Comprehension of ambiguous words in children with poor reading comprehension. Korean Journal of Communication Disorders, 15, 348-356.

Kwak, K. C., Park, H. W., \& Kim, C. T. (2001). Korean Wechsler intelligence scale for children-III (K-WISC-III). Seoul: Seoul Special Education Publishing Co.

Lee, T. Y. (2005). The effect of semantic transparency and lexicality on the decomposition processes of compound nouns. The Korean Journal of Experimental Psychology, 17, 441-459.

Libben, G. (2014). The nature of compounds: a psychocentric perspective. Cognitive Neuropsychology, 31, 8-25.

Mcgregor, K. K., Rost, G. C., Guo, L. Y., \& Sheng, L. (2010). What compound words mean to children with specific language impairment. Applied Psycholinguistics, 31, 463-487.

Monsell, S., Doyle, M. C., \& Haggard, P. N. (1989). Effects of frequency on visual word recognition tasks: where are they? Journal of Experimental Psychology: General, 118, 43-71.

Nagy, W. E., \& Scott, J. A. (2000). Vocabulary processes. Handbook of Reading Research, 3, 269-284.

Nation, K. (2005). Children's reading comprehension difficulties. In M. J. Snowling \& C. Hulme (Eds.), Handbooks of developmental psychology (pp. 248-265). Malden, MA: Blackwell Publishing.

Nation, K., \& Snowling, M. J. (1998). Semantic processing and the development of word-recognition skills: evidence from children with reading comprehension difficulties. Journal of Memory and Language, 39, 85-101.

Nation, K., Clarke, P., \& Snowling, M. J. (2002). General cognitive ability in children with reading comprehension difficulties. British Journal of Educational Psychology, 72, 549-560.

Nation, K., Cocksey, J., Taylor, J. S., \& Bishop, D. V. (2010). A longitudinal investigation of early reading and language skills in children with poor reading comprehension. Journal of Child Psychology and Psychiatry, 51, 10311039.

National Institute of Korean Language. (2005). The modern Korean word frequency II. Seoul: Author.

Nicoladis, E. (2002). The cues that children use in acquiring adjectival phrases and compound nouns: evidence from bilingual children. Brain and Language, 81, 635-648.

Nicoladis, E., \& Krott, A. (2007). Word family size and french-speaking children's segmentation of existing compounds. Language Learning, 57, 201228.

Park, G., Kim, G., Song, Y., Jung, D., \& Jung, I. (2008). Korea Institute for Special Education-Basic Academic Achievement Test (KISE-BAAT). Ansan; Korea Institute for Special Education.

Tabossi, P., \& Zardon, F. (1993). Processing ambiguous words in context. Journal of Memory and Language, 32, 359-372.

Wang, M. S., \& Min, H. S. (1997). Comprehension of Korean grammar. Seoul: Gaemunsa.

Yu, K. J., \& Kim, M. (2017). Characteristics of inference and error in 4-6 grade students with reading comprehension difficulties. Communication Sciences \& Disorders, 22, 284-295.

Zoh, M. H., Lee, J. M., Kim, J. O., Shin, H. J., Lee, K. O., Do, K. S., ... \& Jung, H. S. (2003). Psychology of language. Seoul: Hakjisa. 
Appendix 1. Examples of lexical decision task

\begin{tabular}{|c|c|c|c|c|c|c|c|}
\hline \multicolumn{4}{|c|}{ 고빈도 } & \multicolumn{4}{|c|}{ 저빈도 } \\
\hline \multicolumn{2}{|c|}{ 수식어 점화 } & \multicolumn{2}{|c|}{ 핵심어 점화 } & \multicolumn{2}{|c|}{ 수식어 점화 } & \multicolumn{2}{|c|}{ 핵심어 점화 } \\
\hline 점화 단어 & 목표 단어 & 점화 단어 & 목표 단어 & 점화 단어 & 목표 단어 & 점화 단어 & 목표 단어 \\
\hline 생수 & 물새 & 두부 & 땅콩 & 어둠 & 밤참 & 화재 & 짚불 \\
\hline 나무 & 산나물 & 접시 & 밥그릇 & 새싹 & 씨감자 & 잔디 & 각시풀 \\
\hline 장갑 & 손수건 & 라면 & 칼국수 & 가족 & 집짐승 & 바닥 & 쪽마루 \\
\hline
\end{tabular}




\section{국문초록}

\section{읽기이해부진 아동의 복합명사 처리 특성}

한정인 $\cdot$ 황민아 $\cdot$ 고선희 ${ }^{3}$

1단국대학교 특수교육대학원, ${ }^{2}$ 단국대학교 특수교육과, ${ }^{3 ㄱ ㅗ ㅇ ㅈ ㅜ ㄷ ㅐ ㅎ ㅏ ㄱ ㄱ ㅛ ~ ㅌ ㅡ ㄱ ㅅ ㅜ ㄱ ㅛ ㅇ ㅠ ㄱ ㄷ ㅐ ㅎ ㅏ ㄱ ㅇ ㅝ ㄴ ~}$

배경 및 목적: 읽기이해부진 아동들의 경우, 어휘 지식의 부족이나 비효율적인 어휘의 의미 처리 능력이 읽기 이해에 부정적인 영향을 미칠 수 있다. 이에 본 연구에서는 읽기이해부진 아동들이 복합명사의 의미를 처리하는 데 있어 일반 아동들과 어떠한 차이가 있는지를 조사하였다. 방법: 초등학교 3-5학년의 읽기이해부진 아동 10 명과 일반 아동 10 명을 대상으로 어휘 판단 과제를 실시하였고, 이에 대한 반응정확도와 반응시간을 측정하여 분석하였다. 이때 제시되는 복합명사는 고빈도 조건과 저빈도 조건으로 나뉘고, 점화 단어는 복합 명사의 수식어와 관련이 있는 조건과 복합명사의 핵심어와 관련이 있는 조건으로 나누었다. 결과: 읽기이해부진 아동은 일반 아동들에 비해 전반적으로 정확도가 낮고 반응시간이 길었고, 두 집단 모두 고빈도 조건에 비해 저빈도 조건에서 정확도가 낮고 반응시간이 길었 으며, 두 집단 모두수식어 점화 조건에서보다 핵심어 점화 조건에서 반응시간이 짧았다. 그러나 읽기이해부진 아동은 저빈도 수식어 점 화 조건에서의 정확도가 유의미하게 낮았으며, 저빈도 조건에서 반응시간이 유의미하게 길어짐을 확인할 수 있었다. 논의 및 결론: 읽 기이해부진 아동들은 일반 아동들에 비해 전반적으로 복합명사의 의미를 처리하는 데 어려움을 보였는데 이는 이들의 심성어휘집 내 의 의미연결망이 일반 아동들에 비해 약하게 조직되어 있기 때문일 수 있다. 또한 이들이 복합명사의 통사적인 구조 및 의미 관계를 파 악하는 데 미숙함을 보여 복합명사의 의미 처리에 어려움을 보였을 수 있다.

핵심어: 읽기이해부진, 복합명사, 어휘 판단 과제

\section{참고문헌}

고선희, 최경순, 황민아(2010). 읽기이해부진 아동의 다의어 의미처리 특성. 언어청각장애연구, 15, 348-356.

곽금주, 박혜원, 김청택(2001). 한국판 웩슬러 아동용 지능검사(K-WISC-III). 서울: 도서출판특수교육.

국립국어원(2005). 현대 국어 사용 빈도 조사2. 서울: 국립국어원.

권효원, 김선경, 이혜원(2006). 한글단어재인에서 단어빈도와 의미점화효과의 관계. 한국심리학회지: 실험, 18, 203-220.

김광해(2003). 등급별 국어교육용 어휘. 서울: 박이정.

김명수, 황민아(2017). 읽기이해부진 아동의 대용어 참조해결 특성. 언어청각장애연구, 22, 512-519.

김애화, 유현실, 황민아, 김의정, 고성룡(2010). 초등학생의 읽기이해 능력 예측변인에 관한 연구. 언어청각장애연구, 15, 357-380.

박경숙, 김계옥, 송영준, 정동영, 정인숙(2008). 기초학력검사(Korea Institute for Special Education-Basic Academic Achievement Test, KISE-

BAAT). 안산: 국립특수교육원.

왕문식, 민현식(1997). 국어 문법론의 이해. 서울: 개문사.

유경진, 김미배(2017). 초등 고학년 읽기이해부진아동의 유형에 따른 추론능력과 오류 특성. 언어청각장애연구, 22, 284-295.

이태연(2005). 의미 투명도와 어휘성이 복합명사의 처리과정에 미치는 영향: 수식어와 핵심어의 분리 처리를 중심으로. 한국심리학회지: 실험, 17 , 441-459.

정미란(2009). 초등학교 3-6학년 읽기이해부진 학생의 단어유추. 언어청각장애연구, 14, 275-287.

정미란(2013). 초등학교 3-6학년 읽기이해부진학생의 읽기이해력 예측변인 탐색. 학습장애연구, 10, 79-103.

정부자(2009). 초등학교 저학년 읽기부진 아동의 읽기관련 변인에 관한 연구. 재활복지, 13, 313-327.

조명한, 이정모, 김정오, 신현정, 이광오, 도경수, 이양, 이현진, 김영진, 김소영, 고성룡, 정혜선(2003). 언어심리학. 서울: 학지사.

최경순, 황민아(2010). 읽기이해부진 아동의 의미 처리 특성: 의미 점화 효과. 언어청각장애연구, 15, 168-176. 